\title{
Variability in different lots of commercial bovine serum albumin affects cell multiplication and hatching of rabbit blastocysts in culture
}

\author{
M. T. Kane \\ Department of Physiology, University College, Galway, Ireland
}

\begin{abstract}
Summary. Rabbit morulae were cultured in vitro for 4 days in a synthetic culture medium supplemented with two different lots of commercial bovine serum albumin (BSA) and two different amino acid formulations in a factorial $2 \times 2$ arrangement. One lot of BSA caused complete hatching of a proportion of blastocysts and formation of more than twice as many cells per blastocyst (hatched and unhatched) as that of the second BSA lot which did not cause complete hatching of any blastocysts. The mean cell numbers of hatched blastocysts were more than twice those of non-hatched blastocysts. There was no significant effect of amino acid formulation.
\end{abstract}

\section{Introduction}

In the presence of some samples of commercial bovine serum albumin (BSA) rabbit blastocysts in culture hatch from the zona (Kane, 1972; Maurer, 1978; Kane \& Headon, 1980). In this laboratory we noticed that the blastocysts that hatch are those that appear to be growing most rapidly. To quantitate this effect the present study examined the relationship between blastocyst hatching and cell number in the presence of different lots of commercial BSA.

\section{Materials and Methods}

Embryos

New Zealand White does were induced to superovulate by treatment with FSH (twice daily s.c. injections for 3 days: $0.5 \mathrm{mg} /$ injection) followed 1 day later by simultaneous injection of LH $(0.5$ $\mathrm{mg}$, i.v.) and artificial insemination. FSH and LH were pituitary preparations from Armour, Kankakee, Illinois. Embryos at the early morula stage were collected from the oviduct 44-48 $\mathrm{h}$ after LH injection. Embryos recovered at this stage possess a thick mucin coat laid down by oviducal secretions. The flushing medium was a Hepes-buffered simple salt solution containing $0 \cdot 1 \%$ defatted BSA (Kane, 1979). The embryos from 3-4 rabbits collected on one day were pooled and then washed free of oviduct fluid with repeated changes of the flushing medium. They were placed in culture in $0.5 \mathrm{ml}$ droplets of culture medium under paraffin liquid (Merck, ART. 7162) in tissue culture dishes. Culture dishes were maintained at $38^{\circ} \mathrm{C}$ under a gas phase of $5 \% \mathrm{CO}_{2}$ in air. Embryos were cultured for 4 days and the numbers of non-hatched blastocysts and hatched blastocysts were recorded. Blastocysts were stained according to the method of Grayson (1978), first developed for mammalian oocytes. The method may be briefly described as follows.

Blastocysts in a small drop of medium were placed on a slide precoated with glycerine-albumin, then allowed to dry in air overnight. The air-dried slides were fixed in ethanol-acetic acid $(2: 1 \mathrm{v} / \mathrm{v})$ 
for $45 \mathrm{~min}$, stained in aceto-orcein $\mathrm{HCl}$ for $30 \mathrm{~min}$, then dehydrated successively in $50 \%, 60 \%, 80 \%$ and $100 \%$ ethanol, cleared in xylene and mounted in mounting medium under a cover slip. The number of cells per blastocyst was counted under high power with the aid of an eyepiece micrometer grid.

Culture medium. The basic culture medium contained $108 \mathrm{~mm}-\mathrm{NaCl}, 4 \cdot 78 \mathrm{~mm}-\mathrm{KCl}, 1 \cdot 71 \mathrm{~mm}-$ $\mathrm{CaCl}_{2} .2 \mathrm{H}_{2} \mathrm{O}, 1 \cdot 19 \mathrm{~mm}-\mathrm{KH}_{2} \mathrm{PO}_{4}, 1.19 \mathrm{~mm}-\mathrm{MgSO}_{4} \cdot 7 \mathrm{H}_{2} \mathrm{O}, 25 \mathrm{~mm}-\mathrm{NaHCO}_{3}, 0.5 \mathrm{~mm}$-sodium pyruvate, $1 \mathrm{~mm}$-glucose, 100 units penicillin $\mathrm{G} / \mathrm{ml}, 500 \mu \mathrm{g}$ streptomycin sulphate $/ \mathrm{ml}$ and the vitamins and trace elements of Hams F10 medium (Ham, 1963). This medium was used with the amino acids of F10 medium or of Menezo's B2 medium (Menezo, 1976).

Bovine serum albumin. Two different lot numbers (41F-9300 and 119C-9325) of crystallized BSA (Sigma London Ltd, Poole, Dorset, U.K.; Type A 4378) were used. The two lots of BSA were bought within a 6 -month period and stored at $-20^{\circ} \mathrm{C}$.

Experimental design. The experiment was $2 \times 2$ factorial arrangement of the two lot numbers of BSA (41F-9300 and 119C-9325) and two types of amino acid mixture in a randomized complete block design. BSA was used at a concentration of $1.5 \%$. Each block of the experiment consisted of the morulae collected on 1 day divided equally among the four treatments. The proportions of blastocysts and hatched blastocysts were analysed by orthogonally partitioned $\chi^{2}$ tests with the Yates' correction for continuity. The blastocyst cell counts were analysed by least squares analysis of variance.

\section{Results}

One lot of BSA (No. 41F-9300) caused complete hatching of a proportion of the blastocysts formed whereas the second lot examined (No. 119C-9325) did not (Table 1). BSA No. 41 F-9300 also stimulated a marked and significant increase $(P<0.01)$ in blastocyst cell number as compared with BSA No. 119C-9325 (Table 1).

There was no marked effect of type of amino acid formulation. There was some indication that the Medium B2 amino acids were superior when used with BSA No. 41 F-9300 and the F10 amino acids with BSA No. 119C-9325. However, this interactive effect was not significant $(P>0.05)$.

Examination of the mean \pm s.e.m. cell counts of the hatched blastocysts $(1168 \pm 83,24$ blastocysts) compared with those of the non-hatched blastocysts in treatments with BSA No. 41F-

Table 1. The effect of BSA lot and amino acid formulation on rabbit blastocyst formation, hatching and cell number in culture

\begin{tabular}{lcccc}
\hline & $\begin{array}{c}\text { No. of } \\
\text { morulae }\end{array}$ & $\begin{array}{c}\% \\
\text { blastocysts }\end{array}$ & $\begin{array}{c}\% \text { hatched } \\
\text { blastocysts }\end{array}$ & $\begin{array}{c}\text { Blastocyst } \\
\text { cell counts } \\
\text { (mean } \pm \text { s.e.m.) }\end{array}$ \\
\hline $\begin{array}{l}\text { Individual treatment means } \\
\text { BSA No. 41 F-9300 }\end{array}$ & & & & \\
$\quad+$ F10 amino acids & 51 & 96 & 41 & $710 \pm 50$ \\
$\quad+$ B2 amino acids & 50 & 100 & 20 & $771 \pm 75$ \\
BSA No. 119C-9325 & 51 & 94 & 0 & $409 \pm 165$ \\
$\quad+$ F10 amino acids & 48 & 100 & 0 & $297 \pm 166$ \\
$\quad$ B2 amino acids & & & & \\
$\begin{array}{l}\text { Overall means } \\
\text { BSA }\end{array}$ & 101 & 98 & 31 & $742 \pm 46$ \\
$\quad$ No. 41F-9300 & 99 & 97 & 0 & $345 \pm 25$ \\
$\quad$ No. 119C-9325 & 102 & 95 & 21 & $598 \pm 39$ \\
Amino acid formulations & 98 & 100 & 10 & $572 \pm 53$ \\
$\quad$ F10 & & & & \\
$\quad$ B2 & & & & \\
\hline
\end{tabular}


9300 (the only treatments in which complete hatching occurred) $(549 \pm 27,53$ blastocysts) or the non-hatched blastocysts of all treatments ( $449 \pm 21,104$ blastocysts) showed that the mean cell counts of the hatched blastocysts were $2-3$ times greater than for the non-hatched blastocysts $(P<$ $0 \cdot 01)$.

\section{Discussion}

Three points emerge from this experiment. Firstly, it documents the variability present in the effects of different samples of commercial BSA on embryos. This variability, while well known to workers using commercial BSA for embryo culture, is rarely documented in the literature. Quite clearly a medium containing BSA is not a defined medium.

Secondly, it shows that some samples of BSA stimulate cell division, blastocyst growth and blastocyst hatching. This mitogenic activity of some samples of BSA is potentially very important and present work in this laboratory indicates that it resides in a low molecular weight fraction which can be extracted from the BSA with $5 \%$ formic acid (M. T. Kane, unpublished data).

Thirdly, it shows that hatching of rabbit blastocysts in culture is associated with an increase in cell number. This fact, plus evidence that hatching of blastocysts in culture is not dependent on protease action (Kane, 1983), indicates that hatching of rabbit blastocysts in vitro is probably due to mechanical rupture of the zona and mucin coat (when one is present) by the growing blastocyst. In vivo the situation is clearly different in that blastocyst hatching does not occur. This is probably at least partly due to that fact that in utero the mucin coat laid down in the oviduct is added to by uterine secretion (Boving, 1957). It has also been shown that extensive remodelling of the blastocyst coverings takes place in vivo (Denker \& Gerdes, 1979). There is evidence that in-vitro hatching is reduced by the presence of the mucin coat (Kane, 1975). Photomicrographs of the hatching process and of completely hatched blastocysts formed in the presence of BSA in culture have already been published (Kane, 1972, 1975; Maurer, 1978).

The use of BSA in embryo culture media for a number of species has caused great problems of variability of response between laboratories and even in the same laboratory over time. To take one example of considerable interest because of its potential relevance to work on cattle embryo transfers, the results of Tervit, Whittingham \& Rowson (1972), who cultured cattle embryos in a simple medium supplemented with BSA, have rarely if ever been repeated. This present study indicates that even from the same supplier there may be a clear-cut variation between different lots of BSA in their effects on cell division and blastocyst hatching.

I thank Mrs Patricia Commins for technical assistance, Dr J. P. Hanrahan for help with the statistical analysis; and The National Board for Science and Technology for research funding.

\section{References}

Boving, B.G. (1957) Rabbit egg coverings. Anat. Rec. $127,270$.

Denker, H.-W. \& Gerdes, H.-J. (1979) The dynamic structure of rabbit blastocyst coverings. 1. Transformation during regular preimplantation development. Anat. Embryol. 157, 15-34.

Grayson, K. (1978) An improved method for staining mammalian oocytes. Stain Technol. 53, 115-116.

Ham, R.G. (1963) An improved nutrient solution for diploid Chinese hamster and human cell lines. Expl Cell Res. 29, 515-526.

Kane, M.T. (1972) Energy substrates and culture of single cell rabbit ova to blastocysts. Nature, Lond. 238, 468469.
Kane, M.T. (1975) Inhibition of zona shedding of rabbit blastocysts in culture by the presence of a mucin coat. J. Reprod. Fert. 44, 539-542.

Kane, M.T. (1979) Fatty acids as energy sources for culture of one-cell rabbit ova to viable morulae. Biol. Reprod. 20, 323-332.

Kane, M.T. (1983) Evidence that protease action is not specifically involved in hatching of rabbit blastocysts caused by commercial bovine serum albumin in culture. J. Reprod. Fert. 68, 471-475.

Kane, M.T. \& Headon, D.R. (1980) The role of commercial bovine serum albumin preparations in the culture of one-cell rabbit embryos to blastocysts. J. Reprod. Fert. 60, 469-475. 
Maurer, R.R. (1978). Advances in rabbit embryo culture. In Methods in Mammalian Reproduction, pp. 259-272. Ed. J. C. Daniel, Jr. Academic Press, New York.

Menezo, M.Y. (1976) Milieu synthétique pour la survie et la maturation des gamètes et pour la culture de l'oeuf fécondé. C. r. hebd. Séanc. Acad. Sci., Paris D 282, 1967-1970.

Tervit, H.R., Whittingham, D.G. \& Rowson, L.E.A. (1972) Successful culture in vitro of sheep and cattle ova. J. Reprod. Fert. 30, 493-497.

Received 25 February 1983 